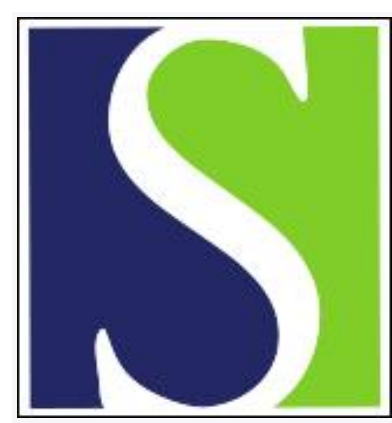

Scand J Work Environ Health 1990;16(6):423-427

https://doi.org/10.5271/sjweh.1765

Issue date: 01 Dec 1990

Cerebrospinal fluid proteins in men with chronic encephalopathy after exposure to organic solvents.

by Barregard L, Wikkelso C, Rosengren LE, Aurell A, Thiringer G, Nilson L, Sallsten G, Haglid KG, Blomstrand C

Affiliation: Department of Occupational Medicine, Sahlgren's University Hospital, Goteborg, Sweden.

This article in PubMed: www.ncbi.nlm.nih.gov/pubmed/2284590

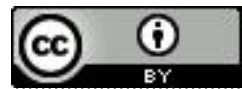




\title{
Cerebrospinal fluid proteins in men with chronic encephalopathy after exposure to organic solvents
}

\author{
by Lars Barregård, ${ }^{1}$ Carsten Wikkelsö, ${ }^{2}$ Lars E Rosengren, ${ }^{3}$ Ann Aurell, ${ }^{3}$ Gunnar Thiringer, ${ }^{1}$ \\ Linda Nilson, ${ }^{1}$ Gerd Sällsten, ${ }^{1}$ Kenneth G Haglid, ${ }^{3}$ Christian Blomstrand ${ }^{2}$
}

\begin{abstract}
BARREGÅRD L, WIKKELSÖ C, ROSENGREN LE, AURELL A, THIRINGER G, NILSON L, SÄLLSTEN G, HAGLID KG, BLOMSTRAND C. Cerebrospinal fluid proteins in men with chronic encephalopathy after exposure to organic solvents. Scand J Work Environ Health 1990;16:423 - 7. Cerebrospinal fluid was examined for 23 patients with chronic toxic encephalopathy after heavy exposure to organic solvents and 23 healthy age-matched referents. No differences were found between the patients and referents with respect to the levels of albumin, immunoglobulin, prealbumin, alpha-1-antitrypsin, beta-2microglobulin, haptoglobin, or the astroglial cell proteins S100 and glial fibrillary acidic protein in the cerebrospinal fluid. The albumin ratio was normal for both the patients and the referents. The patient group had had heavy exposure to organic solvents, but its members had not been exposed for at least one year before the study. It was concluded that, if exposure to organic solvents affects proteins in cerebrospinal fluid, such effects are probably reversible.
\end{abstract}

Key terms: blood-brain barrier, glial fibrillary acidic protein, neurotoxicity, occupational.

Organic solvents have widespread use in paints, glues, and degreasing agents. The nervous system is the critical organ for most organic solvents (1). In addition to the acute narcotic effects of high exposure, chronic neuropsychiatric disease has been indicated by case reports and cohort and case-referent studies (2-5) after long-term occupational exposure. In the 1980s the name "chronic toxic encephalopathy" was coined for this clinical syndrome $(6,7)$. The pathogenetic mechanism is unclear. There are no animal experimental models for most of the solvents (8). Signs of astrogliosis have, however, been reported in rodents after longterm exposure to various solvents $(9,10)$. Adverse effects on membrane function have also been suggested (7). In two previous studies cerebrospinal fluid (CSF) has been examined in patients with chronic toxic encephalopathy, and also in healthy men exposed to organic solvents $(11,12)$. In these investigations signs of slight immunoactivation (11) and increased permeability of the blood-CSF barrier $(11,12)$ were reported.

The aim of the present investigation was to study CSF proteins in a group of men with clear signs of chronic toxic encephalopathy after heavy, although not recent, exposure to organic solvents. In the protein analyses we also included those astroglial markers found to be affected in earlier animal experiments.

1 Department of Occupational Medicine, Sahlgren's University Hospital, Göteborg, Sweden.

2 Department of Neurology, Sahlgren's University Hospital, Göteborg, Sweden.

${ }^{3}$ Institute of Neurobiology, University of Göteborg, Göteborg, Sweden.

Reprint requests to: Dr L Barregård, Department of Occupational Medicine, St Sigfridsgatan 85, S-412 66 Göteborg, Sweden.

\section{Subjects and methods}

\section{Subjects}

Among all the patients examined between 1976 and 1984 at the clinic of occupational medicine, those patients were selected whose final diagnosis was chronic toxic encephalopathy caused by exposure to organic solvents. The patients selected also had to meet the following criteria: (i) sex male, (ii) age not exceeding 60 years at the time of the study, (iii) a cumulative exposure to organic solvents corresponding to at least 10 years of work at the Swedish hygienic standard, ${ }^{4}$ 20 years of work at 0.5 times the standard, and so forth (for mixtures of solvents, the sum of the fractions of the hygienic standards were used), as evaluated by an experienced occupational hygienist, (iv) no exposure to solvents for at least one year at the time of the study, (v) symptoms and signs clearly indicating diffuse encephalopathy (eg, memory deterioration, concentration difficulties, irritability, and emotional instability) at the examination by specialists in occupational medicine, neurology, and (in most cases) psychiatry, (vi) psychometric test performance [test battery (13) including verbal, logical, spatial and perceptual functions, memory, and manual dexterity] supportive of diffuse brain damage as evaluated by an experienced psychologist, (vii) exclusion of other diseases that might result in neuropsychiatric symptoms and/or brain damage (alcoholism, traumatic injuries, presenile Alzheimer's disease, cerebrovascular disease, depression, etc) by necessary examinations, (viii) exclusion

${ }^{4}$ Examples for the most common solvents used by patients in the present study (hygienic standard from 1984): white spirit ( $\leq 22 \%$ aromatic compounds) $500 \mathrm{mg} / \mathrm{m}^{3}$, xylene $350 \mathrm{mg} / \mathrm{m}^{3}$, methyl ethyl ketone $300 \mathrm{mg} / \mathrm{m}^{3}$. 
of diseases that might affect CSF proteins (diabetes, long-term hypertension, nerve root compression, etc).

Out of the 122 patients with a diagnosis of chronic toxic encephalopathy only $\mathbf{3 4}$ met these rather strict criteria. The most common reasons for exclusion from the study were that the cumulative exposure had not been unequivocally high enough, that high alcohol consumption could not be excluded, or that the patient was too old. As nine of the 34 eligible patients refused to take part in the study and lumbar puncture was unsuccessful for two others, the final number of patients examined in the present study was 23 . Most of them had been exposed to solvents as painters (seven house painters, four ship painters, and four car painters). The mean exposure time was 27 (range $11-42$ ) years.

Twenty-three healthy age-matched ( \pm 4 years) men served as referents. They had to meet the following criteria: no previous or present exposure to organic solvents, no neurological or psychiatric disease or alcohol abuse, no disease that might affect CSF proteins (see the list given for the patients). Nineteen of the referents were selected from workplaces known by the authors. Nine were physicians, six had other whitecollar jobs, and four were blue-collar workers. Another four referents were patients who underwent spinal anesthesia in connection with urological surgery. In all, 30 subjects who met the inclusion criteria had to be asked before 23 agreed to participate in the study.

\section{Medical examination}

Each participant's medical history was taken and a new general and neurological examination (except for the four subjects who underwent spinal anesthesia) was carried out. Blood samples were analyzed for serum proteins, liver enzymes, and levels of vitamin $B_{12}$ and folic acid (other screening tests had been performed at the initial examination). A lumbar puncture was performed with the subject in the supine position. CSF and blood were stored at $-20^{\circ} \mathrm{C}$ until analyzed.

\section{Analyses of the cerebrospinal fluid}

Protein content was determined as described by Lowry et al (14). Albumin, immunoglobulin (Ig) G, prealbumin, alpha-1-antitrypsin, and haptoglobin were mea- sured with the use of electroimmunoassay (15). Beta2 -microglobulin and the astroglial cell proteins $\$ 100$ and glial fibrillary acidic protein were determined with enzyme-linked immunosorbent assay $(10,16,17)$. The albumin ratio [CSF albumin/S albumin $(\mathrm{S}=$ serum)] was calculated and used as an indicator of the blood$\mathrm{CSF}$ barrier function. The IgG index (CSF IgG/S $\mathrm{IgG}) /(\mathrm{CSF}$ albumin/S albumin) was used to estimate the local production of $\mathrm{IgG}$ within the central nervous system. Furthermore, erythrocytes, polymorphonuclear leukocytes, monocytes, and phagocytes were counted in the CSF. In cases of contamination by blood, the ratios of red blood cells in the CSF versus those of the whole blood were used to correct the CSF protein levels for the fractions of plasma proteins that could have contaminated the CSF.

\section{Electrophoretic examinations}

Absorption chromatography was performed with the use of the IgG fractions of rabbit antiserum against human serum proteins (Dako, Copenhagen, Denmark, product A 208) (18).

The antihuman serum proteins were coupled to cyanogen bromide-activated $(10 \mathrm{mg}$ of $\mathrm{IgG} / \mathrm{ml}$ of Sephadex) Sepharose $4 B^{\circledR}$ (spherical agarose gel particles, Pharmacia, Uppsala, Sweden) and packed on columns K 15/30, volume $48 \mathrm{ml}$ (Pharmacia).

Unconcentrated CSF was passed through the columns and eluted in two fractions, one containing enriched CSF proteins (fraction I) and the other containing proteins antigenically identical to serum proteins (fraction II). Fraction I was eluted with $0.15 \mathrm{M}$ tris-hydrochloric acid in $0.5 \mathrm{M}$ sodium chloride $(\mathrm{pH}$ 8.0) and fraction II with $0.15 \mathrm{M}$ glycin hydrochloric acid in $0.5 \mathrm{M}$ sodium chloride ( $\mathrm{pH} 2.8$ ). The samples were concentrated with the use of Pellicon molecular filters (nominal molecular weight limit $-10^{4}$, Millipore) to $3-4 \mathrm{~g} / 1$.

Isoelectric focusing of the CSF and serum was performed in flat beds of polyacrylamide gel, $11 \times 25 \times$ $0.1 \mathrm{~cm} \mathrm{(19).} \mathrm{The} \mathrm{gel} \mathrm{contained} \mathrm{a} \mathrm{total} \mathrm{of} 5 \%(\mathrm{~g} /$ $100 \mathrm{ml}$ of gel) polyacrylamide $(4.8 \%$ acrylamide and $0.2 \% \mathrm{~N}, \mathrm{~N}$-methylene bisacrylamide), and the $\mathrm{pH}$ range was 3.5-9.5. Ampholine (LKB products, Bromma, Sweden) was added to a final concentration of $2 \%$

Table 1. Age, exposure time, and neurological findings for the 23 patients with chronic toxic encephalopathy and the 23 healthy referents.

\begin{tabular}{|c|c|c|c|c|c|c|c|}
\hline & \multicolumn{2}{|c|}{ Age (years) } & \multicolumn{2}{|c|}{ Exposure time (years) } & \multicolumn{3}{|c|}{ Neurological findings } \\
\hline & Mean & Range & Mean & Range & $\begin{array}{c}\text { None } \\
\text { pathological } \\
(\mathrm{N})\end{array}$ & $\begin{array}{l}\text { Cerebellar } \\
\text { dysfunction } \\
\text { (N) }\end{array}$ & $\begin{array}{c}\text { Sensory } \\
\text { peripheral } \\
\text { neuropathy } \\
(\mathrm{N})\end{array}$ \\
\hline $\begin{array}{l}\text { Patients } \\
\text { Referents }\end{array}$ & $\begin{array}{l}53 \\
54\end{array}$ & $\begin{array}{l}44-60 \\
41-65\end{array}$ & 27 & $11-42$ & $\begin{array}{l}11 \\
19 b\end{array}$ & $\underbrace{9^{a}}$ & $\mathbf{8}^{a}$ \\
\hline
\end{tabular}

a Six patients had signs of both cerebellar dysfunction and sensory neuropathy.

b Four referents were not examined by a neurologist. 
and had the following composition: $\mathrm{pH} 4-6(0.7 \mathrm{ml})$, 5-7 $(0.7 \mathrm{ml}), 9-11(0.4 \mathrm{ml})$, and $3.5-10.0(1.8 \mathrm{ml})$. Twenty microliters of unconcentrated CSF and $20 \mu \mathrm{l}$ of diluted serum $(1 / 200)$ were added to application clots at the most cathodal part of the gel.

Silver staining was performed essentially according to the method of Oakley et al (20).

\section{Statistical analyses}

In the comparisons of the exposed group with the referents, Student's t-test for paired observations was used. For correlation between variables, linear and multiple linear regression analyses were used.

\section{Results}

Age, exposure time, and neurological findings are shown for the subjects in table 1 . There were slight signs of cerebellar dysfunction and slight sensory peripheral neuropathy in several patients but no abnormalities in the referents. Two patients had pathologically increased levels of liver enzymes, and one patient and one referent had concentrations of vitamin $B_{12}$ that were below the normal limit.

For three patients the CSF was contaminated with blood. For all the other patients and referents the cell findings were normal, with $0-4$ monocytes $/ \mathrm{ml}$, and no differences were found between the patients and the referents.

The serum and CSF protein levels are shown in table 2. The total serum proteins and the $\mathrm{IgG}$ index were higher in the patient group. Their CSF-IgG was, however, not significantly increased, and their albumin ratios were lower than those of the referents. There were no differences between the patients with neurological findings and the other patients with respect to CSF al- bumin, the albumin ratio, or the IgG index. Isoelectric focusing of the total CSF proteins showed slight signs of blood-CSF barrier dysfunction in two patients and three referents. There were no abnormalities in the CSF-enriched fractions of either group.

The correlations between age, exposure time, and the various proteins in the combined group of exposed patients and unexposed referents are shown in table 3. Total CSF protein, CSF albumin, albumin ratio, CSF IgG and CSF alpha-1-antitrypsin were highly intercorrelated, as could be expected. In the exposed group there were no significant correlations between the exposure time and the various protein levels. The S100 level was slightly negatively correlated with age and CSF protein. When the multiple linear regression analysis was used, it was shown that the variation in the albumin ratio was almost completely a result of the variation in CSF albumin.

Table 2. Serum (S) and cerebrospinal fluid (CSF) protein values for the 23 patients with chronic toxic encephalopathy and the 23 healthy referents. (IgG = immunoglobulin $\mathrm{G}$ )

\begin{tabular}{|c|c|c|c|c|}
\hline \multirow{2}{*}{ Analyses } & \multicolumn{2}{|c|}{ Patients } & \multicolumn{2}{|c|}{ Referents } \\
\hline & Mean & SD & Mean & SD \\
\hline $\begin{array}{l}\text { S protein (g/l) } \\
\text { S albumin (g/l) } \\
\text { S IgG (g/l) } \\
\text { CSF protein (mg/l) } \\
\text { CSF albumin (mg/l) } \\
\text { CSF igG (mg/l) } \\
\text { CSF beta-2-microglobulin (mg/l) } \\
\text { CSF prealbumin (mg/l) } \\
\text { CSF alpha-1-antitrypsin (mg/l) } \\
\text { CSF haptoglobin (mg/l) }\end{array}$ & $\begin{array}{c}77.6^{*} \\
44.0 \\
11.9 \\
545 \\
245 \\
41.5 \\
1.17 \\
21.5 \\
8.2 \\
4.0\end{array}$ & $\begin{array}{c}4.6 \\
4.3 \\
2.5 \\
125 \\
77 \\
19.4 \\
0.19 \\
1.5 \\
3.4 \\
3.1\end{array}$ & $\begin{array}{c}9.3 \\
42.7 \\
11.0 \\
479 \\
265 \\
36.4 \\
1.27 \\
21.3 \\
9.0 \\
3.2\end{array}$ & $\begin{array}{c}6.5 \\
4.8 \\
1.8 \\
115 \\
96 \\
12.8 \\
0.43 \\
3.0 \\
2.6 \\
2.2\end{array}$ \\
\hline $\begin{array}{l}\text { Albumin ratiob } \\
\text { lgG index }\end{array}$ & $\begin{array}{l}5.6 \\
0.62^{*}\end{array}$ & $\begin{array}{l}1.7 \\
+\quad 0.06\end{array}$ & $\begin{array}{l}6.2 \\
0.54\end{array}$ & $\begin{array}{l}2.1 \\
0.07\end{array}$ \\
\hline $\begin{array}{l}\text { CSF S100 (pmol/l) } \\
\text { CSF glial fibrillary acidic } \\
\text { protein (pmol/I) }\end{array}$ & $\begin{array}{l}446 \\
116\end{array}$ & $\begin{array}{r}151 \\
49\end{array}$ & $\begin{array}{l}471 \\
103\end{array}$ & $\begin{array}{r}165 \\
37\end{array}$ \\
\hline
\end{tabular}

$\therefore$ Patients $N=20$, referents $N=16$

b See the Methods section for a definition.

- Patients $N=21$, referents $N=22$.

- $P<0.05$.

Table 3. Correlations between age, proteins in the cerebrospinal fluid (CSF), and proteins in serum in the combined group of patients with chronic toxic encephalopathy and unexposed referents $(N=46)$. Prealbumin, haptoglobin and beta-2-microglobulin were not significantly correlated with any other variable (not shown in the table). ( $\mathrm{gG}=$ immunoglobulin $\mathrm{G}, \mathrm{GFA}=\mathrm{glia}$ fibrillary acidic)

\begin{tabular}{|c|c|c|c|c|c|c|c|c|c|c|c|}
\hline & Age & $\begin{array}{c}\text { CSF } \\
\text { protein }\end{array}$ & $\begin{array}{c}\text { CSF } \\
\text { albumin }\end{array}$ & $\begin{array}{l}\text { CSF } \\
\lg G\end{array}$ & $\begin{array}{l}\text { Albumin } \\
\text { ratio }\end{array}$ & $\begin{array}{l}\lg G \\
\text { index }\end{array}$ & $\begin{array}{l}\text { CSF } \\
\text { alpha-1- } \\
\text { anti- } \\
\text { trypsin }\end{array}$ & $\begin{array}{l}\text { CSF } \\
\text { S100 }\end{array}$ & $\begin{array}{c}\text { CSF } \\
\text { GFA } \\
\text { protein }\end{array}$ & $\begin{array}{l}\text { Serum } \\
\text { protein }\end{array}$ & $\begin{array}{l}\text { Serum } \\
\text { albumin }\end{array}$ \\
\hline $\begin{array}{l}\text { CSF protein } \\
\text { CSF albumin }\end{array}$ & $\begin{array}{l}0.16 \\
0.10\end{array}$ & $0.81^{\star \star \star}$ & & & & & & & & & \\
\hline CSF IgG & 0.14 & $0.81^{* * *}$ & $0.74^{* * *}$ & & & & & & & & \\
\hline Albumin ratio a & 0.23 & $0.79^{\star \star \star *}$ & $0.94^{* * *}$ & $0.72^{* * *}$ & $-0,15$ & & & & & & \\
\hline $\begin{array}{l}\text { CSF alpha-1-antitrypsin } \\
\text { CSF a }\end{array}$ & $\begin{array}{r}0.04 \\
-0.02\end{array}$ & $\begin{array}{l}0.26 \\
0.43^{\dagger}\end{array}$ & $0.44^{\dagger}$ & $0.52^{\star * \star}$ & $\begin{aligned} &-0.15 \\
&+ 0.42^{\dagger}\end{aligned}$ & -0.08 & & & & & \\
\hline CSF S100 & $-0.33^{\star}$ & $-0.36^{\star}$ & $-0.34^{\star}$ & -0.28 & $-0.31^{*}$ & -0.11 & -0.32 & & & & * \\
\hline CSF GFA protein ${ }^{b}$ & -0.05 & $0.35^{\star}$ & $0.35^{*}$ & 0.25 & 0.24 & 0.03 & 0.13 & 0.03 & & & \\
\hline Serum protein & -0.21 & 0.24 & -0.04 & $0.36^{*}$ & -0.19 & 0.54 *** & 0.11 & -0.21 & 0.15 & & \\
\hline Serum albumin & -0.33 & -0.11 & 0.25 & 0.10 & -0.08 & 0.22 & 0.04 & -0.10 & 0.26 & 0.38 & \\
\hline Serum lgG & -0.07 & 0.13 & -0.02 & $0.53^{* * *}$ & -0.06 & 0.11 & 0.26 & 0.08 & 0.08 & $0.54^{\cdots * *}$ & 0.20 \\
\hline
\end{tabular}

a See the Methods section for a definition.

b $N=43$.

* $P<0.05,{ }^{\star \star \star *} P<0.001,{ }^{\dagger} P<0.005$. 


\section{Discussion}

No evidence of changes in the CSF protein pattern was seen in the patients with chronic toxic encephalopathy after long-term exposure to organic solvents. In an earlier Finnish study (11), there were, similarly, no significant differences in the group mean values of CSF proteins between 33 solvent-exposed subjects and 46 healthy referents. However in 22 of the subjects with recent exposure to solvents, but no disease caused by such exposure, five had a slightly increased CSF albumin level, possibly indicating a blood-CSF barrier dysfunction.

In a Swedish study (12) no differences were seen in the mean CSF protein levels between solvent-exposed patients and referents. However, three of the $17 \mathrm{pa}-$ tients had increased albumin ratios. There was also a significant positive correlation between exposure time and albumin ratio. For seven out of 17 patients a relative increase in a protein band with Ip 4.7 was seen in the isoelectric focusing of the CSF-enriched proteins. The patient group included workers with ongoing exposure and also workers whose exposure to solvents had ceased many years earlier.

In the present study we used strict inclusion criteria to make the diagnosis chronic toxic encephalopathy as certain as possible. We were also able to differentiate between possible permanent effects on the CSF protein pattern and transient effects from solvent exposure, as the patients were examined at least one year after exposure ceased. No signs of blood-CSF barrier dysfunction were found in the patient group as compared with the referents. The power of the present study permits an $80 \%$ chance of detecting a $20 \%$ increase in albumin concentration or albumin ratio in the patients as compared with the values of the referents ( $\alpha=0.05$, one-tailed). In our opinion a reasonable conclusion is that, if solvents affect the blood-CSF barrier function, such effects are probably reversible.

In the present study no correlation was seen between exposure time and the albumin ratio. This finding is not in agreement with the results of a previous Swedish study (12). However, exposure time is a crude measure of total exposure to solvents. With the classification of that study, all of our 23 patients would be considered to have been "heavily exposed."

The previous finding of a relative increase in a protein band with Ip 4.7 could not be reproduced in the present study.

No increase in astroglial proteins was shown in the CSF of the solvent-exposed group. Such an increase has been demonstrated in brain tissue in animal studies after exposure to neurotoxic agents $(9-10)$. Similar changes might occur in the human brain in toxic encephalopathy caused by organic solvents. Even so, in this study these proteins were not significantly increased in the CSF. In addition, in other diseases with marked astrogliosis, the determination of CSF astroglial protein concentrations has not been a very suc- cessful method of differentiation between patients and referents (21). This lack of success might be explained by the limited leakage of these proteins into the CSF from astrogliotic brain tissue and the substantial normal variation between individuals.

The referents in our study, including, for example, nine physicians, were not socioeconomically comparable with the patients. If anything, they should, however, be expected to have a better general health status than solvent-exposed workers, and therefore the selection of referents could hardly explain the "negative" results.

In conclusion, CSF proteins do not seem to be affected one year or more after heavy exposure to organic solvents. CSF analyses could, however, be justified as a method of detecting other neurological diseases.

\section{Acknowledgments}

This study was supported by the Swedish Work Environment Fund.

Technical assistance was given by Ms A Kling and Ms M Edvardson.

\section{References}

1. Axelson $\mathrm{O}$, Hane $\mathrm{M}$, Hogstedt $\mathrm{C}$. Current aspects of solvent-related disorders. In: Zenz C, ed. Developments in occupational medicine. Chicago IL: Year Book Medical Publishers, 1980:237-48.

2. Axelson $\mathrm{O}$, Hane M, Hogstedt $\mathrm{C}$. A case-referent study on neuropsychiatric disorders among workers exposed to solvents. Scand J Work Environ Health 1976;3: $14-20$.

3. Hane M, Axelson O, Blume J, Hogstedt C, Sundell L, Ydreborg B. Psychological function changes among house painters. Scand J Work Environ Health 1977;3: 91-9.

4. Linz DH, de Garmo PL, Morton WE, Wiens AN, Coull BM, Maricle RA. Organic solvent-induced encephalopathy in industrial painters. J Occup Med 1986;28:11925.

5. Baker EL, Fine LJ. Solvent neurotoxicity: the current evidence. J Occup Med 1986;28:126-9.

6. World Health Organization, Regional Office for Europe. Chronic effects of organic solvents on the central nervous system and diagnostic criteria: report of a Joint World Health Organization/Nordic Council Ministers Working Group. World Health Organization, Regional Office for Europe, Copenhagen, 1985.

7. Cranmer JM, Goldberg L, ed. Neurobehavioral effects of solvents. Neurotoxicology 1986;7(4):1-95.

8. Spencer PS, Schaumburg HH: Organic solvent neurotoxicity: facts and research needs. Scand J Work Environ Health 1985;11(suppl 1):53-60.

9. Rosengren LE, Kjellstrand P, Haglid KG. Long term neurotoxicity of styrene: a quantitative study of glial fibrillary acidic protein (GFA) and S100. Br J Ind Med 1989;46:316-20.

10. Rosengren LE, Aurell A, Kjellstrand P, Haglid KG. Astrogliosis in the cerebral cortex of gerbils after long-term exposure to 1,1,1-trichloroethane. Scand J Work Environ Health 1985;11:447-55.

11. Juntunen J, Taskinen E, Lusito M, Iivanainen M, Nur- 
minen M. Cerebrospinal fluid cells and proteins in patients occupationally exposed to organic solvents. J Neurol Sci 1982;54:413-25.

12. Wikkelsö C, Ekberg K, Lillienberg L, et al. Cerebrospinal fluid proteins and cells in men subjected to long-term exposure to organic solvents. Acta Neurol Scand 1984; 70(suppl 100):113-9.

13. Hogstedt $C$, Hane M, Axelsson O. Diagnostic and health care aspects of workers exposed to solvents. In: Zenz $\mathrm{C}$, ed. Developments in occupational medicine. Chicago IL: Year Book Medical Publishers, 1980:249-58.

14. Lowry OH, Rosebrough NI, Lewis Farr A, Randall RJ. Protein measurement with the folin phenol reagent. J Biol Chem 1951;193:265-75.

15. Laurell C-B. Quantitative estimation of proteins by electrophoresis in agarose gel containing antibodies. Anal Biochem 1966;15:45-52.

16. Bjerrum OW, Lage S, Hansen OE. Measurement of beta-2-microglobulin in human cerebrospinal fluid by ELISA technique. Acta Neurol Scand 1986;75:177-80.
17. Aurell A, Rosengren LE, Wikkelsö C, Nordberg G, Haglid KG. The S-100 protein in cerebrospinal fluid: a simple ELISA method. J Neurol Sci 1989;89:157-64.

18. Wikkelsö C, Blomstrand C, Rönnbäck L. Separation of cerebrospinal fluid specific proteins - a methodological study. J Neurol Sci 1980;44:247-57.

19. Vesterberg O. Isoelectric focusing of proteins in thinlayers of polyacrylamide gel. Sci Tools 1973;20:122-29.

20. Oakely BR, Kirsch DR, Morris NR. A simplified ultrasensitive silver stain for detecting proteins in polyacrylamide gels. Anal Biochem 1980;105:361-3.

21. Noppe M, Crols R, Andries D, Lowenthal A. Determination in human cerebrospinal fluid of glial fibrillary acidic protein, S-100 and myelin basic protein as indices of non-specific or specific central nervous tissue pathology. Clin Chem Acta 1986;155:143-50.

Received for publication: 29 March 1990 